\title{
Eco-Innovative Solutions for the Processing of Technogenic Mineral Resources
}

\author{
Gotfrids Noviks \\ Engineering faculty \\ Rezekne Academy of Technologies \\ Rezekne, Latvia \\ Gotfrids.Noviks@rta.lv
}

\begin{abstract}
The inorganic wastes and residues formed during the production and operation process are valuable technogenic minerals, the rational treatment of which can reduce the amount of non-renewable natural mineral resources.

The relatively low reuse of technogenic mineral resources is currently associated with specific characteristics of these resources. They have a wide and multiplex diversity in composition and structure, and hence a wide, uneven range of physical and chemical properties that require a complex approach to assessing the potential for developing each resource. In addition, it is necessary to evaluate the ecological and energy efficiency, technical feasibility and economic efficiency of the processing of these resources in comparison with the production of natural mineral substances from traditional technologies. A methodology for the evaluation production of potentially new goods from technogenic mineral waste is proposed. Parameters such as multifunctionality of new products, energy and resource saving, lifetime increase, reduction of negative impact on the environment, maintenance or improvement of production quality compared to original quality are taken into account. The basis for the analysis of these possibilities and methodology of assessment of eco-energetic efficiency to justify the usefulness of mineral wastes processing are given. Possibilities of using this approach for the development of mineral waste from construction and demolition recycling technologies for the production of composites, binders, fillers and monolithic structures are shown.
\end{abstract}

Keywords-mineral waste, waste managment, recycling, ecoefficiency, ecoindicators,product properties.

\section{INTRODUCTION}

It is known that significant part of waste produced in the industry have inorganic nature [1,2] In our previous investigations $[3,4]$ we declared that all solid waste which are inorganic in the terms of chemistry are mineral waste. They include: the remnants of the construction and repair, debris, byproducts of mining, construction and demolition waste, glass and glass- use industrial waste, ceramic waste, combustion waste, and so on .

Mineral waste compared to organic waste is less susceptible to natural degradation processes. Consequently, it does not fit into the natural process of substance circulation in ecosystems and its volume is constantly increasing. At the same time, since these substances are less exposed to chemical and biochemical transformations, they are often not harmful to the environment (except for the specific waste group - classified as hazardous waste); Main effect of them are the passive pollution of the territory and their ineffective disposal into the dumpsites. However, all these mineral wastes have retained virtually unchanged the components from which they were made, as well as partly the original structure and physical properties, and thus potentially have been used either directly or after the relevant processing to serve as raw material for the production of new products by replacing natural raw materials - hence reducing the intensity of depletion of non-renewable resources and the amount of landfilled waste to be disposed of. [5] All these wastes should therefore be considered as technogenic minerals and valued at the same level as natural resources. There are two main reasons for this situation - first and foremost, the technologies for extraction and processing of natural resources were built, developed, equipped with the relevant techniques and materials - and became traditional and economically efficient. Secondly, the composition, structure and condition of technogenic resources are very uneven, complex, variable, so the properties are not permanent. Their volumes and formation sites are also variable and subject to a variety of random factors. As a result, traditional mineral resource processing technologies cannot be technically or economically profitable for the processing of techno resources. You need your own specific approach to the development of recycling technologies for these resources. [7, 8.9,].

In the .European Waste Classification[10] according to Regulation no. $849 / 2010$ all the waste are divided into two groups: non-hazardous and hazardous and 51 categories. Of these categories, mineral resources include: metallic wastes $(0.61 .0 .62 .0 .63)$, glass wastes (0.71), mineral waste from construction and demolition (1.21), combustion wastes (1.24), soils (1.26), mineral wastes from waste treatment and stabilized wastes $(12.8,13)$, other mineral wastes $(1.22 .1 .23 .1 .25)$. Waste such as discarded equipment (0.8), vehicles $(0.81)$, battraries and accumulator wastes $(0.841)$, mixed and undifferentiated materials (102) may also be partly related to mineral resources. The group recycable wastes (0.6.0.7) is not very precise in terms of composition 
because consists mainly from metal and glass. Analyzing the total quantities of non-hazardous waste produced from 2010 onwards, the European Union shows that it is gradually increasing, but the growth is not high in just 6 years it was only about $5 \%$.(fig. 1 )

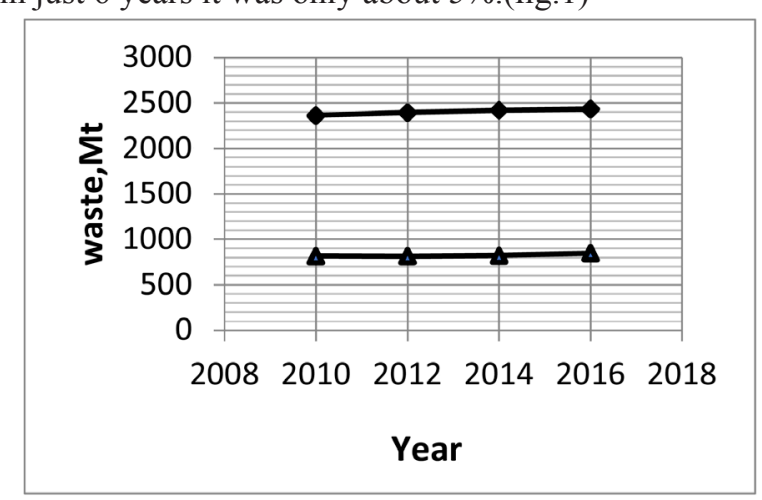

Fig.1.Volumes of nonhazardous wastes in EU generated

The recycling of waste is around $38 \%$ of the total amount of waste produced. This means that the remaining $62 \%$ or around $1600 \mathrm{Mt}$ of waste is collected annually in the environment. The total amount of non-hazardous waste in Latvia increased from $1430.2 \mathrm{kt}$ in 2010. up to $2466.4 \mathrm{kt}$ in 2016 - more than 1.7 times (Fig.2) [6].

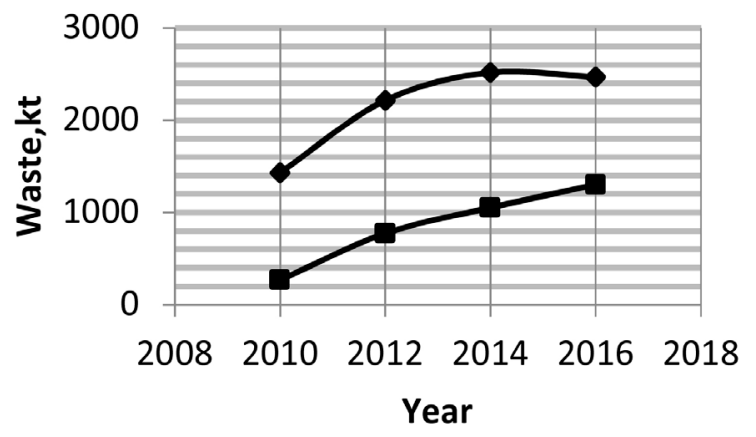

Fig.2.. Volumes of nonhazardous wastes in Latvia generated and recycled

But must be mentioned that the percentage of recycled waste in 2016 increased also -from 19\% to 53\% of the total.

\section{MATERIALS AND METHODS}

In our research, we paid attention to mineral waste, which is currently not recycled or recycled in very limited quantities. These are: mineral waste from construction and demolition, combustion wastes, soils, other mineral wastes. (fig.3)

Their total volume generated in 2016 in the European Union, achieved $1609 \mathrm{Mt}$, in Latvia consequently$486 \mathrm{kt}(66 \%$ and $20 \%$ of the total non-hazardous waste respectively) (tab1).

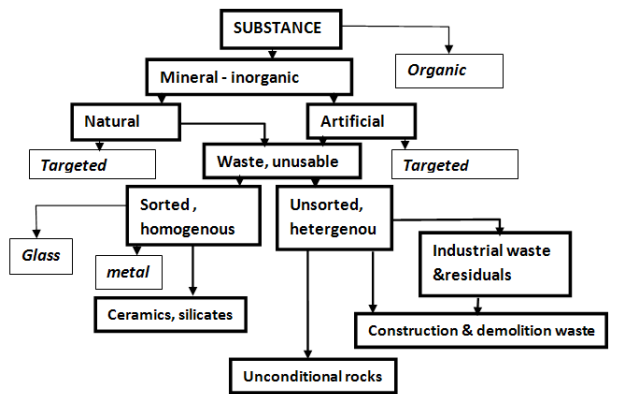

Fig.3. Mineral technogenic resources .In bold blocks - analysed wastes.

It should be understood that in order to obtain a highquality eco-innovative product with better qualities (at least not lower, but better upcycled) than for the former product, with high-value (hightech) characteristics, a serious phase of raw material research is obligatory using modern hardware and research methods. resulting from processing .

Otherwise, the product obtained as a result of waste processing will be uncompetitive and unsuitable to use.

Therefore, the comparison of techno-mineral waste recycling methods and the quality of the obtained product and the justification of the optimal variant is needed. Currently there are a number of indicators of ecological, economic, energy efficiency evaluation and calculation methods of different directions [12,13, 14]. The paper analyzes them and adapts to the conditions of mineral waste recycling.

TABLE 1 Mineral waste generated in EU and Latvia (2010-2016)

\begin{tabular}{|c|c|c|c|c|c|c|c|c|}
\hline Year & Country & $\begin{array}{l}\text { Total hazardous + } \\
\text { non-hazardous, }\end{array}$ & $\begin{array}{c}\text { Total } \\
\text { non-haz- } \\
\text { ardous }\end{array}$ & $\begin{array}{c}\text { Mineral } \\
\text { wastes from construc- } \\
\text { tion and demolition }\end{array}$ & Soils & $\begin{array}{c}\text { Combustion } \\
\text { wastes }\end{array}$ & $\begin{array}{c}\text { Other } \\
\text { mineral } \\
\text { wastes }\end{array}$ & $\begin{array}{c}\text { Total } \\
5+6+7+8+9\end{array}$ \\
\hline 1 & 2 & 3 & 4 & 5 & 6 & 7 & 8 & 9 \\
\hline \multirow{2}{*}{2010} & EU ,Mt & 2,460 & 2,364 & 328 & 420 & 111 & 742 & 1601 \\
\hline & Latvia, kt & 1,498 & 1,430 & 144 & 0 & 153 & 31 & 328 \\
\hline \multirow{2}{*}{2012} & $\mathrm{EU}, \mathrm{Mt}$ & 2,491 & 2,395 & 329 & 406 & 122 & 781 & 1638 \\
\hline & $\begin{array}{c}\text { Latvia, } \\
\mathrm{kt}\end{array}$ & 2,310 & 2,214 & 396 & 31 & 174 & 30 & 631 \\
\hline \multirow{2}{*}{2014} & $\mathrm{EU}, \mathrm{Mt}$ & 2,515 & 2,420 & 306 & 459 & 115 & 754 & 1634 \\
\hline & $\begin{array}{c}\text { Latvia, } \\
\mathrm{kt}\end{array}$ & 2,621 & 2,517 & 571 & 9 & 45 & 29 & 654 \\
\hline \multirow[b]{2}{*}{2016} & $\mathrm{EU}, \mathrm{Mt}$ & 2,535 & 2,435 & 335 & 485 & 112 & 677 & 1609 \\
\hline & $\begin{array}{l}\text { Latvia, } \\
\text { kt }\end{array}$ & 2,533 & 2,466 & 387 & 13 & 46 & 40 & 486 \\
\hline
\end{tabular}




\section{RESULTS AND DISCUSSION}

Thus, the process of developing mineral waste recycling methods and technologies should consist of the following stages: 1.Justification for recycling need 2.Setting a recycling target 3.Technological and physical research of mineral resources 4.Evaluation of the physical effects on the formation of minerals and new properties. 5.Designing of the experiments, conducting experiments and testing the obtained material 6.Assessment of technical feasibility, ecological and economic efficiency of processes. 7.Development of a Production Technology Pilot Project.

Let us look at each of these stages. In the initial 1. stage phase must be answered the question - is there a need for some sort of action on these wastes or would it be best to simply dump it into a landfill or otherwise integrate it into the environment.

For example, if they are not a hazardous waste group they can be used in the reconstruction of mechanically degraded areas, changing relief, in building engineering objects (embankments, roads, dams). The need in recycling of mineral waste is related to -Danger to the environment and man, -Large volumes and continuous growth of waste, - Economic disadvantages and environmental hazards for landfill storage,

- Valuable components or useful properties of this waste, -Inadequacy with any use variant directly without prior processing.

The information obtained in the first stage is used in the stage 2 toformulate therecyclingtarget.Itmaybedirectedto:

(a) waste itself, the need to eliminate or reduce (regulate) its quantity; (b) the production of a predetermined product from this mineral waste. In the first case, further research is related to a broad assessment of possible uses of mineral resources and a reduction in their volume. In the second case, the studies are performed within a narrow range of potential product design characteristics. In the Stage 3 the research methodology is set according to the goals formulated in the second stage. If the task is to avoid the total volume of the mineral waste, it should be taken into account that the mineral waste is a resource and that it is necessary to find the most useful way of avoiding it by obtaining the maximum benefit from it. This means that in this case also a complex analysis of this substance is required - to determine the macro-composition, mineral and chemical composition, structure and state parameters, physical and chemical properties.

At all stages of the study, the results should be evaluated using the available data base on the physical, chemical properties, structure and composition of existing analogue materials. Research may be interrupted at any stage if the compliance of the properties of the mineral waste with any existing and used material is found [15]. If the task is to use this mineral resource to produce a predefined product, the research program consists of the following steps: - Precisely defines the essential requirements and properties to be met by the final product (according to existing analogues). - mineral properties are studied - Compliance or non-compliance of these properties is determined.

The main task of Stage 4 is to determine, on the basis of the physical effects database, the possible physical fields and processes that could result in the creation of a set of required properties corresponding to the intended use of the recycled resource. [16] - Experiment planning is being carried out in Stage 5. The aim of the experiments - to check the results of the selected physical effects, to obtain samples of the final product, to evaluate the conformity of their properties to the properties of the planned reference material. Stage 6 specifies the technologies and regimes for the potential treatment and recycling of the mineral resource and analyzes them according to the criteria of ecological, technical feasibility and economic efficiency. The most mineral wastes are not biodegradable and can not be used as a fuel for thermal energy. Their processing must be based on changing physical properties of materials by mechanical, thermal treating or using other physical fields such as electromagnetic, acoustic, nuclear radiation, thermo-chemical , biochemical, mycrobiological processes.

In all cases, it is necessary to identify the types of potential exposures to which the material may be exposed and the possible outcomes of this exposure (tab.2).

The only determining factors for the change of material properties are their composition, structure and condition at different levels - from submicroscopic to macroscopic. External physical and chemical fields are the means by which these parameters can be changed. Thus, all types of exposure to minerals that determine the possible changes in the physical fields of a mineral can be divided into 4 groups: 1.Changes in energy status. 2. Changes in link strengths between the different structural elements of the substance at different scales. 3. Changes in phase condition (including state of aggregation). 4. Changes in composition (including chemical). Practical tasks of mineral processing are in many cases directly related to the last process. Inturn, theycanbedividedintothefollowingtypesofactivity: 1. Extraction of useful components from the original mineral mass 2. Separation of inappropriate, harmful components from the original useful mineral mass. 3. Combining different components into a single composite material to produce the product with the required properties.

The construction and demolition waste in many cases consistsofamixtureofsuchdifferentcomponents: concrete, 
reinforced concrete, clay bricks, silicate bricks, glass, metal, soil admixtures, organic materials (plastic, wood). Assessing the feasibility of rational use of these wastes begins with determining their aggregate composition. The best way to use is when the raw material is the least exposed to the processing, but at the same time the quality of the final material is the best of the available variants and its producing technology has the least negative effect on the environment- princips most quality - less losses (MQ-LL).. This means that mineral waste can only be used directly if its use is in line with the MQ-LL principle. Recycling starts from a basic stage - pre-preparation of a mineral resource that includes operations:

Primary sorting by composition - metal, glass, organic, and by components size: (granulometric composition). Modern materials processing technologies allow to effectively implement these waste preparation works, incl. separation of iron reinforcement from reinforced concrete structures [17]. As a result of the pre-preparation, an intermediate product is obtained which is more even in the composition and structure than the primary waste. Iron and glass components can already be used in traditional waste recycling technologies. Organic compaunds may be subjected to incineration, resulting in heat energy, or exposed biological recycling for biofuel production.

The mineral part of the waste according to the size of the components and their composition may in turn be used in different ways. 1. Monolithic pieces - according to their composition as: - just elements for New Building Structures, Bs - additional elements to create macrocomposite structures.Mbs

2. Dispersed material as a

-filler for cement FCe

-filler for composite FCo

-binder $\mathrm{Bi}$

-adsorbent Ad

-heat insulation Hi

- alloy (fusion) - sintering, vitrified material Fu

TABLE 2

Physical, Chemical and Biological Field Effects which are Perspective for Mineral Waste Processing

\begin{tabular}{|c|c|c|}
\hline $\begin{array}{l}\text { Action } \\
\text { nature }\end{array}$ & Processes & $\begin{array}{l}\text { Physical effects, changes in } \\
\text { composition, state, structure, } \\
\text { properties }\end{array}$ \\
\hline \multirow{3}{*}{$\begin{array}{l}\text { Mechan- } \\
\text { ical }\end{array}$} & Disintegration & $\begin{array}{l}\text { Structure, granulometric compo- } \\
\text { sition, strength, specific surface, } \\
\text { fluid permeability, reactivity }\end{array}$ \\
\hline & $\begin{array}{l}\text { Consolidation } \\
\text { (compacting) }\end{array}$ & $\begin{array}{l}\text { Density, strength, elasticity, per- } \\
\text { meability, chemical reactivity }\end{array}$ \\
\hline & $\begin{array}{l}\text { Separation } \\
\text { (sorting, rinsing, } \\
\text { dusting)) }\end{array}$ & $\begin{array}{l}\text { Homogenization, homogeneity in } \\
\text { composition, structure, properties }\end{array}$ \\
\hline
\end{tabular}

\begin{tabular}{|c|c|c|}
\hline \multirow{4}{*}{ Hydraulic } & Dissolution & $\begin{array}{l}\text { Formation of solutions, release of } \\
\text { soluble and insoluble compo- } \\
\text { nents }\end{array}$ \\
\hline & $\begin{array}{l}\text { Hydrolysis } \\
\text { (solvolize) }\end{array}$ & $\begin{array}{l}\text { Formation of new chemical } \\
\text { compounds }\end{array}$ \\
\hline & $\begin{array}{l}\text { Hydration } \\
\text { (solvation) }\end{array}$ & $\begin{array}{l}\text { Formation of new compounds } \\
\text { (hydrates, solvates) }\end{array}$ \\
\hline & Extraction & Extraction of components \\
\hline \multirow{6}{*}{ Thermal } & Dehydration & $\begin{array}{l}\text { Water is released from the } \\
\text { material }\end{array}$ \\
\hline & $\begin{array}{l}\text { Thermomechanical } \\
\text { Destruction }\end{array}$ & $\begin{array}{l}\text { Disintegration (changes in } \\
\text { structure, granulometry, and all } \\
\text { related properties) }\end{array}$ \\
\hline & $\begin{array}{l}\text { First-order phase } \\
\text { transitions (changes in } \\
\text { physical state, melting, } \\
\text { vitrification) }\end{array}$ & $\begin{array}{l}\text { Melt formation - changes all } \\
\text { properties incl. structure, compo- } \\
\text { sition, density, porosity }\end{array}$ \\
\hline & \begin{tabular}{|l|} 
Second-order phase \\
transitions (polymorphic \\
transformations)
\end{tabular} & $\begin{array}{l}\text { Changes of crystalline structure } \\
\text { and all properties }\end{array}$ \\
\hline & Sintering & $\begin{array}{l}\text { Changes in strength and elasticity } \\
\text { parameters, porosity, permeabili- } \\
\text { ty, density, humidity changes }\end{array}$ \\
\hline & $\begin{array}{l}\text { Reduction-oxidation } \\
\text { reactions }\end{array}$ & $\begin{array}{l}\text { Changes in chemical composi- } \\
\text { tion, formation of oxides, release } \\
\text { of components }\end{array}$ \\
\hline \multirow[t]{2}{*}{$\begin{array}{l}\text { Electro- } \\
\text { magnetic }\end{array}$} & Electrothermal Heating & $\begin{array}{l}\text { All effects according to thermal } \\
\text { effects }\end{array}$ \\
\hline & Electrolysis & Partitioning in components \\
\hline \multirow{3}{*}{ Chemical } & $\begin{array}{l}\text { chemical synthesis } \\
\text { reactions }\end{array}$ & New substance formation \\
\hline & $\begin{array}{l}\text { Chemical decomposition } \\
\text { reactions }\end{array}$ & New substance formation \\
\hline & $\begin{array}{l}\text { Replacement and ex- } \\
\text { change reactions }\end{array}$ & New substance formation \\
\hline $\begin{array}{l}\text { Microbio- } \\
\text { logical }\end{array}$ & $\begin{array}{l}\text { Microbial leaching } \\
\text { (bioleaching) }\end{array}$ & Release of chemical elements \\
\hline
\end{tabular}

The properties of the product to be designed and the physical fields to be used for their production are listed in Table 3

An assessment of the ecological, economic and social efficiency of the selected process for the recycling of mineral waste can be done using developed methods for assessing the eco-energy, socio-efficiency of production -BASF's Eco-EfficiencyAnalysis Methodology [20], 
Delft University of Technology [21,22] and others. The recycling of waste should be aimed at the development of recycling technologies, the use of which gives the final product with a quality not less than the quality of the original product - the upcycling principle now predominantly practiced in place of the "downcycling" principle when a product with a lower value is obtained at each subsequent processing stage compared to previous quality [23,24] During analysis process we divided the evaluation criteria into two groups - the first characterizing the production area - recycling of waste, the second - the quality of the product obtained. In the first group we included 4 indicators - energy consumption -E, gas emissions- G, water consumption - L, secondary waste- $\mathrm{W}$

TABLE3

THE DEFINING CHARACTERISTICS OF THE FINAL PRODUCT TO BE DESIGNED AND THE PHYSICAL PROCESSES OF THEIR FORMATION

\begin{tabular}{|c|c|c|}
\hline $\begin{array}{c}\text { Intended } \\
\text { product }\end{array}$ & Key Features & $\begin{array}{c}\text { Physical Fields and Process- } \\
\text { es Used }\end{array}$ \\
\hline \begin{tabular}{|c|} 
Building \\
details, blocks \\
of monolithic \\
waste $(\mathrm{Bs})$ \\
\end{tabular} & $\begin{array}{l}\text { Geometric dimensions, } \\
\text { shape, strength, frost and } \\
\text { moisture resistance }\end{array}$ & $\begin{array}{l}\text { Mechanical, hydraulic treat- } \\
\text { ment, heating. }\end{array}$ \\
\hline \begin{tabular}{|c|} 
Composite \\
constructions \\
of macroele- \\
ments (Mbs) \\
\end{tabular} & $\begin{array}{c}\text { Geometric dimensions, } \\
\text { shape, strength, frost and } \\
\text { moisture resistance }\end{array}$ & $\begin{array}{l}\text { Mechanical, hydraulic treat- } \\
\text { ment, heating. }\end{array}$ \\
\hline $\begin{array}{c}\text { Cement Filler } \\
\text { (Fce) }\end{array}$ & $\begin{array}{c}\text { Degree of dispersion, } \\
\text { adhesion, adsorption, spe- } \\
\text { cific surface and surface } \\
\text { energy, strength }\end{array}$ & $\begin{array}{c}\text { Mechanical treatment } \\
\text { (shredding, sieving), surface } \\
\text { activation }\end{array}$ \\
\hline \begin{tabular}{|c|} 
Filler for \\
composite \\
materials FCo
\end{tabular} & $\begin{array}{c}\text { Degree of dispersion, } \\
\text { adhesion, adsorption, spe- } \\
\text { cific surface and surface } \\
\text { energy, strength }\end{array}$ & $\begin{array}{l}\text { Hydraulic processing, thermal } \\
\text { mechanical (pressing),electro- } \\
\text { magnetic fields }\end{array}$ \\
\hline Binder Bi & $\begin{array}{c}\text { Chemical composition } \\
\left(\mathrm{CaO}, \mathrm{SiO}_{2}, \mathrm{Al}_{2} \mathrm{O}_{3}, \mathrm{Fe}_{2} \mathrm{O}_{3}\right) \\
\text { Degree of dispersion, } \\
\text { adhesion, adsorption, spe- } \\
\text { cific surface and surface } \\
\text { energy, strength }\end{array}$ & $\begin{array}{c}\text { Mechanical treatment } \\
\text { (shredding, sieving), surface } \\
\text { activation }\end{array}$ \\
\hline Adsorbent Ad & $\begin{array}{c}\text { Specific surface, adsorp- } \\
\text { tion }\end{array}$ & $\begin{array}{c}\text { surface activation, crushing,- } \\
\text { milling }\end{array}$ \\
\hline $\begin{array}{c}\text { Heat insula- } \\
\text { tion } \mathrm{Hi}\end{array}$ & $\begin{array}{c}\text { Thermal properties } \lambda, \alpha, \\
\text { c, porosity, pore structure, } \\
\text { humidity }\end{array}$ & $\begin{array}{l}\text { Thermal treatment, mechani- } \\
\text { cal compacting }\end{array}$ \\
\hline Alloy & $\begin{array}{c}\text { Melting, sintering, } \\
\text { vitrification temperature } \\
\text { and energy, specific heat } \\
\text { capacity }\end{array}$ & Thermal efficacy \\
\hline sieving, $\mathrm{Gr}$ & $\begin{array}{c}\text { Components difference } \\
\text { in particle size }\end{array}$ & Mechanical treatment \\
\hline $\begin{array}{l}\text { Separation } \\
\text { in Physical } \\
\text { Fields }\end{array}$ & $\begin{array}{c}\text { Components difference } \\
\text { by physical properties } \\
\text { (density, elasticity, mag- } \\
\text { netic, electrical, thermal) }\end{array}$ & Relevant Physical Fields \\
\hline Melting, Me & $\begin{array}{c}\text { Componens difference by } \\
\text { melting point }\end{array}$ & Thermal efficacy \\
\hline $\begin{array}{l}\text { Extraction, } \\
\text { Ex }\end{array}$ & $\begin{array}{c}\text { Components difference } \\
\text { in solubility in different } \\
\text { solutions and at different } \\
\text { temperatures } \\
\end{array}$ & $\begin{array}{c}\text { Hydraulic efficacy, also with } \\
\text { heat fields }\end{array}$ \\
\hline \begin{tabular}{|l|} 
Biological ex- \\
traction .Bex
\end{tabular} & $\begin{array}{c}\text { The ability of the com- } \\
\text { ponents to be exposed to } \\
\text { microorganisms }\end{array}$ & Microbiological effects \\
\hline 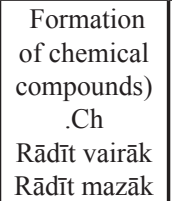 & $\begin{array}{l}\text { Chemical activity in } \\
\text { different fields }\end{array}$ & $\begin{array}{l}\text { Effects of chemical fields, } \\
\text { including thermal reactions }\end{array}$ \\
\hline
\end{tabular}

In the second group was included the integrated properties of the produced product as durability of the product $\mathrm{D}$, compliance with the product's quality criteria rate $\mathrm{R}$, range of applications (its amplification) - A, product safety - S.

All these indicators are converted into dimensionless proportions. In addition, the indicators of the first group are calculated as the ratio of the value of the parameter to be evaluated for the traditional production of the product to the same new production parameter: $\mathrm{IE}=\mathrm{E} 0 / \mathrm{EM}, \mathrm{IG}=\mathrm{G} 0 / \mathrm{GM}, \mathrm{IL}=\mathrm{L} 0 / \mathrm{LM}, \mathrm{IQ}$ $=\mathrm{Q} 0 / \mathrm{QM}$ product is attributed to the quality criterion of the traditionally made product: $\mathrm{ID}=\mathrm{DM} / \mathrm{D} 0, \mathrm{IR}=\mathrm{RM} / \mathrm{R} 0, \mathrm{IA}=\mathrm{AM} / \mathrm{A} 0, \mathrm{IS}=\mathrm{SM} / \mathrm{S} 0$ As a result, the efficiency of the new products from the techno-minerals is higher, the larger is each of these indicators. Figures less than one indicate the inefficiency of the new process or production according to this indicator.. By displaying these indicators in the diagram, the total efficiency indicator will be proportional to the corresponding field of the limited area (Fig.4).

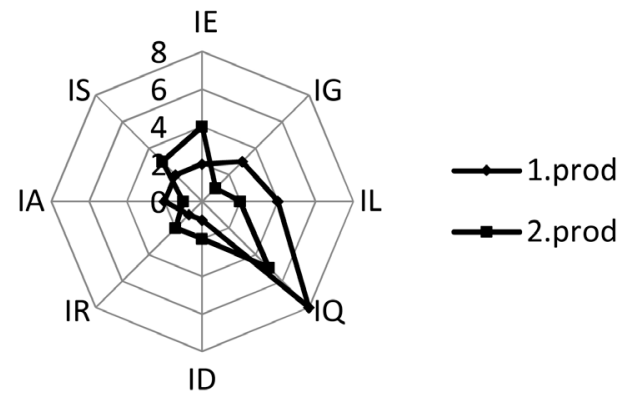

The choice of weight coefficients should be based on the degree of hazard to the environment caused by the recycling of techno-waste and the importance of the quality of the product obtained. If the calculation $\Phi$ $\leq 1$, the selected processing technology is not useful. With regard to the assessment of the construction waste recycling process and the efficacy of the final product, the following weightings may be recommended, taking into account existing experience: $\mathrm{E}=0.6, \mathrm{G}=0.8, \mathrm{~L}=0.4, \mathrm{~W}$ $=0.3, \mathrm{D}=0.7, \mathrm{R}=0.9, \mathrm{~A}=0.4, \mathrm{~S}=0.6$.

Coefficients may be specified and adapted to the recycling of a particular waste and production. At present, programs $[25,26,27]$ have been developed that enable the use of a comprehensive database for calculating the indicators needed to assess the eco-efficiency of the relevant technological processes throughout the production life cycle.

\section{CONCLUSION}

Industrial mineral waste according to its composition, structure and physical properties is a valuable resource that can be effectively used as a source of natural primary resources in many cases, thereby reducing the use of natural resources, increasing energy and eco-efficiency in the production sector. But this is achievable if, on the basis of resource physical and chemical properties exploration and acquantance with the possibility of physical processes acting on the material to obtain the required quality 
product, the optimum technology of processing the resource is developed. In this case, it is possible to obtain technologically valuable, high quality eco-innovative end products with high added value. This means that the most important stage in solving the problems of mineral waste utilization is the in-depth study of physical processes and field interaction with substances and the implementation of a rational technological process according to the obtained results.

\section{REFERENCES}

[1] [https://issuu.com/.../-global_waste_management_outlook-20

[2].http://siteresources.worldbank.org/INTURBANDEVELOPMENT/ Resources/336387-1334852610766/Chap5.pdf

[3] G.Noviks.Basis of optimal mineral inorganic waste processing methods, in Environment.Technology.Resources: Proceedings of the 6-th International Scientific and Practical Conference, June2022,2007,Rezekne,pp87-101,

[4] G.Noviks. Physico-technical approach to design of composites from mineral and polymer technogenic resources in Environment.Technology.Resources: Proceedings of the 10th International Scientific and Practical Conference, June2022,2015,Rezekne,pp162-169,]

[5] Reena Shah United Nations Statistics Division Workshop on Environment Statistics (Addis Ababa, 16-20 July 2007)

[6] https://ec.europa.eu/eurostat/web/environment/waste/database

[7] L.D.Poulikaqkos, C.Papadaskalopoulou, B.Hofko, F.Gschosser, A.Cannone at.al. Harvesting the unexplored potential of European waste materials for road construction, Resources, Conservationand recycling . Vol.116. January 2017. pp.32-44,

[8] Ana Jamenez-RiveroJustoGarcia-Navarro, Exploring factors influencing post-consumer gypsum recycling and landfilling in the European Union, Resources, Conservation and RecyclingVol.116,January 2017,pp116-123

[9] Lovins, L. Hunter ,Rethinking production in State of the World 2008,

[10] EWC-STAT 4 .European Waste Classification for Statistics, version 4 Commission Regulation (EU) No 849/2010 of 27 September 2010 amending Regulation (EC) No 2150/2002 of the European Parliament and of the Council on waste statistics.

[11] Sustainability of Construction Materials Woodhead Publishing Series in Civil and Structural Engineering 2nd Edition • 2016

[12] Eco-indicator 99. Manual for designers.A damage oriented method for life cycle impact assesment . Ministry of housing, spatial planning and environment, the Netherlands , 2000

[13] Saling, P., Kicherer, A., Dittrich-Krämer, B. et al. Int J LCA (2002) 7: 203. https://doi.org/10.1007/BF02978875

[14] Advances in Building Technology Proceedings of the International Conference on Advances in Building Technology 4-6 December 2002, Hong Kong, ChinaVolume II, 2002, Pages 1391-1398.
[15] Hossain, M. U., Poon, C. S., Lo, I. M., \& Cheng, J. C. (). Comparative environmental evaluation of aggregate production from recycled waste materials and virgin sources by LCA. Resources, Conservation and Recycling, 109, 2016, 67-77.

[16] Moh, Y,Latifah -->Abd Manaf. (2017). Solid waste management transformation and future challenges of source separation and recycling practice in Malaysia. Resources, Conservation and Recycling, 116, 1-14.

[17] Кириченко А. С., Букин А. В. Advanced technological processes for the extraction of scrap from reinforced concrete structures in remote areas Передовые технологические процессы извлечения лома из железобетонных сооружений в отдаленных районах // Молодой ученый. — 2014. — №16. - C. 74-78. — URL https:// moluch.ru/archive/75/12728/ (retreived: 09.02.2019).

[18] Bex Corale L. Brierley Microbial mining Published in: Scientific American, 247, 42 - 50, 1982

[19] Torma,A.E.JOM,The microbiological extraction of less common metals June 1989, Volume 41, Issue 6, 32-35

[20].https://search.yahoo.com/search?p=basf+eco+efficiency\&fr=yfp$\mathrm{t}-\mathrm{s} \& \mathrm{fp}=1 \&$ toggle $=1 \& \mathrm{cop}=\mathrm{mss} \& \mathrm{ei}=\mathrm{UTF}-8 \&$ guccounter $=1$

[21] Arne Eik,Solveig Steinmo, Håvard Solem, et.al Eco-efficiency in Recycling Systems : Evaluation Methods \& Case Studies for Plastic Packaging, January 2002www.researchgate.net/profile/ Helge_Brattebo/

[22] https://www.cedelft.eu/en/publications/286/eco-efficiency-fromidea-to-operational-concept

[23] Zhuo, C. and Levendis, Y. A. 2014. "Upcycling waste plastics into carbon nanomaterials: A review". Journal of Applied Polymer Science. 131, 4,2014

[24] Sung, K.; Cooper, T.; Kettley, S. Individual Upcycling Practice: Exploring the Possible Determinants of Upcycling Based on a Literature Review. Sustainable Innovation 2014 Conference. Copenhagen.

[25] Design + Environment - a Global Guide to Designing Greener Goods", Lewis, H., Gertsakis, J., Grant, T., Morelli, N. \& Sweatman, A., New York: Greenleaf Publishing 2001.

[26] user's guide: strategic waste minimization initiative (SWAMI) version 2. 0: A software tool to aid in process analysis for pollution prevention for SWAMI by U.S. environmental protection agency (SuDoc EP 1.8:W 28/14) 1992

[27] Clean Process Advisory System (CPAS) http://cpas.mtu.edu/ cencitt/report9798/cpas.htmlUser's guide: Strategic Waste Minimization Initiative (SWAMI) version 2. 0: A software tool to aid in process analysis for pollution prevention. United States: N. p., 1992. Web.User's guide: Strategic Waste Minimization Initiative (SWAMI) version 2. 0: A software tool to aid in process analysis for pollution prevention. United States: N. p., 1992. Web.User's guide: Strategic Waste Minimization Initiative (SWAMI) version 2. 0: A software tool to aid in process analysis for pollution prevention. United States: N. p., 1992. Web. 